\title{
TREATMENT OF NON-SPECIFIC CHRONIC LOW BACK PAIN: RESISTANCE TRAINING WITH OR WITHOUT USING WEIGHTS?
}

\author{
TRATAMENTO DA LOMBALGIA CRÔNICA INESPECÍFICA:TREINAMENTO RESISTIDO COM OU SEM PESOS?
}

TRATAMIENTO DE LA LUMBALGIA CRÓNICA INESPECÍFICA: ¿ENTRENAMIENTO DE FUERZA CON O SIN PESAS?

Camila Teixeira de Oliveira' (ID (Physical trainer)

Michel Kanas² (DD

(Physician)

Marcelo Wajchenberg 3 (ID

(Physician)

1. Universidade Federal de São Paulo/UNIFESP, Center for Sports Traumatology, São Paulo, SP, Brazil. 2. Universidade Federal de São Paulo/UNIFESP, Center for Sports Traumatology, São Paulo, SP, Brazil. 3. Universidade Federal de São Paulo/UNIFESP, Center for Sports Traumatology, São Paulo, SP, Brazil.

\section{Correspondence}

Camila Teixeira de Oliveira Rua Mairi, 62, Indianópolis, São Paulo, SP, Brazil. 04082-030. camilaolvpersonal@gmail.com

\begin{abstract}
Introduction: Dysfunction of the core muscles contributes to the persistence of pain in patients with chronic low back pain. Evidence shows that the active approach is beneficial in the rehabilitation of these patients. However, there is uncertainty as to the most effective methods or form of exercise, as the literature offers little guidance in this regard. Objective: To analyze and compare the impact on quality of life, function, flexibility, abdominal strength and abdominal fat rate in patients with non-specific chronic low back pain after a program of resistance training using two different forms of exercise. Methods: Thirty individuals, aged between 18 and 65 years, participated in the study. Twenty performed physical training program twice a week for eight weeks, and ten did not perform any physical exercises, but received guidance and pain relief. The physically active individuals were randomly divided in two groups and received similar resistance training, focusing on the same muscle groups. Ten performed training with dumbbells and bodybuilding machines (TRCP) and ten did not use this equipment (TRSP). All were assessed before and after the intervention, through questionnaires on quality of life and function, and tests for flexibility, abdominal strength and measurement of the abdominal fat rate. Results: In the intra-group comparison (initial vs eight weeks), there were no significant differences in quality of life in any of the groups. However, regarding function, the three groups showed significant improvement, with TRSP showing the best evolution. For flexibility and abdominal strength gain, TRCP showed the best evolution in both instruments. For decrease in abdominal fat rate, only TRCP showed significant differences. In the intergroup comparison, there were no significant differences for any of the evaluated outcomes. Conclusion: The two exercise programs were effective in improving function, flexibility and abdominal strength in patients with chronic, non-specific low back pain. However, there were no statistically significant differences in any of the outcomes in the comparison between groups. Level evidence II, Comparative prospective study.
\end{abstract}

Keywords: Low back pain; Exercise therapy; Resistance training.

\section{RESUMO}

Introdução: A disfunção da musculatura do tronco contribui para a persistência da dor em pacientes com lombalgia crônica. As evidências demonstram ser benéfica a abordagem ativa para reabilitação desses pacientes, porém, existem incertezas sobre qual método ou modalidade mais eficaz, uma vez que a literatura existente oferece poucas orientações nesse aspecto. Objetivo: Analisar e comparar o impacto na qualidade de vida, função, flexibilidade, força abdominal e percentual de gordura abdominal em pacientes com lombalgia crônica inespecífica, após a realização de programa de treinamento resistido utilizando duas modalidades diferentes. Métodos: Trinta indivíduos, entre 18 e 65 anos, participaram do estudo; sendo que 20 realizaram um programa de treinamento físico duas vezes por semana, durante oito semanas, e dez não realizaram exercícios físicos, porém receberam orientações e medicação analgésica. Os indivíduos ativos fisicamente foram divididos em dois grupos, aleatoriamente, e receberam treinamento resistido similar focado nos mesmos grupos musculares. Dez realizaram treinamento com halteres e aparelhos de musculação (TRCP) e dez não utilizaram esses equipamentos, realizando apenas exercícios funcionais (TRSP). Todos foram avaliados antes e após a intervenção, por meio de questionários de qualidade de vida e função, além de testes de flexibilidade, força abdominal e mensuração do percentual de gordura abdominal. Resultados: Na comparação intragrupo (inicial x oito semanas), não houve mudança significativa na qualidade de vida de nenhum dos grupos. No entanto, quanto à função, os três grupos apresentaram melhora significativa, com o TRSP demonstrando melhor evolução. Para flexibilidade e ganho de força abdominal, o TRCP demonstrou melhor evolução em ambos os instrumentos. Para diminuição do percentual de gordura abdominal, somente o TRCP apresentou diferenças significativas. Na comparação intergrupos, não houve diferença estatisticamente significativa para nenhum dos desfechos avaliados. Conclusão: Os dois programas de exercícios foram eficazes para melhora da função, flexibilidade eforça abdominal em pacientes com lombalgia crônica inespecífica. No entanto, não houve diferença estatisticamente significativa em nenhum dos desfechos na comparação entre os grupos. Nível de evidência ll, Estudo prospectivo comparativo.

Descritores: Lombalgia; Terapia por exercício; Treinamento de força. 


\section{RESUMEN}

Introducción: La disfunción de la musculatura del tronco contribuye para la persistencia del dolor en pacientes con lumbalgia crónica. La evidencia muestra que un enfoque activo para la rehabilitación de estos pacientes es beneficioso. Sin embargo, existe incertidumbre sobre qué método o modalidad es más eficaz, ya que la literatura existente ofrece poca orientación al respecto. Objetivo: Analizary comparar el impacto en la calidad de vida, función, flexibilidad, fuerza abdominal y porcentaje de grasa abdominal en pacientes con lumbalgia crónica inespecífica, luego de realizar un programa de entrenamiento de resistencia utilizando dos modalidades diferentes. Métodos: Participaron del estudio 30 personas, entre 18 y 65 años; veinte de los cuales se sometieron a un programa de entrenamiento físico dos veces por semana durante ocho semanas, y diez no realizaron ejercicios físicos, pero recibieron orientación y medicación analgésica. Los individuos físicamente activos se dividieron en dos grupos, al azar, y recibieron un entrenamiento de resistencia similar, centrándose en los mismos grupos musculares. Diez se sometieron a entrenamiento con mancuernas y aparatos de musculación (TRCP) y diez no utilizaron esos equipos, realizando ejercicios funcionales (TRSP). Todos fueron evaluados antes y después de la intervención, mediante cuestionarios de calidad de vida y función, además de pruebas de flexibilidad, fuerza abdominaly medición del porcentaje de grasa abdominal. Resultados: En la comparación intragrupo (inicial $x 8$ semanas), no hubo cambios significativos en la calidad de vida en ninguno de los grupos. Para la función, los tres grupos mostraron una mejora significativa, con TRSP mostrando una mejor evolución. En cuanto a flexibilidad y aumento de la fuerza abdominal, TRCP se desempeñó mejor en ambos instrumentos. Para disminuir el porcentaje de grasa abdominal, solo TRCP mostró diferencias significativas. En la comparación intergrupal, no hubo diferencias estadísticamente significativas para ninguno de los resultados evaluados. Conclusión: Los dos programas de ejercicio fueron efectivos para mejorar la función abdominal, la flexibilidad y la fuerza en pacientes con dolor lumbar crónico inespecífico. Sin embargo, no hubo diferencias estadísticamente significativas en ninguno de los resultados en la comparación entre grupos. Nivel de evidencia Il, Estudio prospectivo comparativo.

Descriptores: Lumbalgia; Terapia por ejercicio; Entrenamiento de fuerza.

\section{INTRODUCTION}

Low back pain can be defined by the presence of pain between the last costal arch and the lower gluteal fold. This symptom affects both sexes, and may vary in intensity and duration. The characteristics of pain, the symptoms presented on physical examination, changes in imaging tests and duration, are the criteria used to classify low back pain., ${ }^{1,2}$

When the structure that generates low back pain cannot be discovered, it is called idiopathic or nonspecific low back pain. If the duration of low back pain exceeds twelve weeks, it is considered chronic. ${ }^{3,4,5}$

Low back pain is one of the most frequent causes of disability in modern society, with a prevalence of $60-85 \%$; it is the second biggest cause of seeking medical care and at any time, between 15 and $20 \%$ of adults have the symptom, with the vast majority (90\%), of non-specific cause. ${ }^{6}$

Therapy with physical exercises aims to strengthen the muscles of the trunk and increase the range of motion, with the aim of reducing pain by gaining conditioning, muscular endurance and improving posture. In addition to the physical benefits, exercise can also bring emotional and psychological benefits leading to decreased pain and disability. ${ }^{5}$

Several types of exercise have positive results in the treatment of low back pain, with little evidence of which one would be the most efficient?

The aim of the study was to analyze and compare the change in life quality, function, flexibility, abdominal strength and abdominal fat rate in patients with chronic non-specific low back pain, after carrying out an eight-week resistance training program with or without weights.

\section{METHODOLOGY}

The study included patients seen at the spine outpatient clinic, aged between 18 and 65 years old, diagnosed with chronic non-specific low back pain and completing the informed consent form (ICF). The following non-inclusion criteria were used: previous spine surgery, severe obesity (BMl> 35), pregnancy and disabling pain for exercising. Participants who had two absences or muscle injuries during the training period were excluded from the study.
Before starting the program, participants were introduced to the study, and, according to their availability to participate in two weekly training sessions at the proposed times, they were initially allocated to two groups: physically active group ( $N=20)$ and control group $(N=10)$. Among the participants in the physically active group, there was randomization, in two groups: resistance-training group with weights $(R T G 1=10)$ and resistance training group without weights ( RTG2 = 10).

The initial physical evaluation consisted of the "sit and reach" test to measure flexibility, abdominal flexion test in 1 minute to assess abdominal strength, in addition to the measurement of the abdominal skinfold, using Sanny scientific body fat adipometer, capacity 0 to $65 \mathrm{~mm}$, tolerance $0.5 \mathrm{~mm}$ to $65 \mathrm{~mm}$, resolution in tenths of millimeters, thermo-injectable ABS. The EQ-5D questionnaire was used to assess quality of life and the Oswestry Disability Index questionnaire for functional capacity. ${ }^{8-12}$

The periodization of the exercises was planned for two sessions per week, with an average duration of 60 minutes, 10 minutes of warming up on an exercise bike, elliptical or treadmill, followed by 10 minutes of dynamic stretching exercises for both active groups. Subsequently, patients were directed to their respective strength exercises. The first weekly session included 8 exercises aimed at the trunk stabilizing musculature (core): back, abdomen and buttocks. ${ }^{13}$ The second session was aimed at muscle balance, consisting of 8 exercises targeted to: chest, shoulders, lower limbs, biceps and triceps. Exercises were selected for the same muscle groups, considering agonist muscles, with the difference that RTG1 used overload with conventional equipment and dumbbells found in the weight room (Figures 1, 2, 3 and 4), and the RTG2 used overload created by rubber bands, TRX Suspension Training, swiss ball, step platforms or variants in the initial position of the exercises, changing the level of difficulty and respecting the principle of biological individuality of each patient (Figures 5, 6, 7 and 8). The control group (CG) received guidance on low back pain and analgesic medication.

After 8 weeks of intervention, the groups were reevaluated and filled out the same questionnaires initially applied. During this period, the CG 


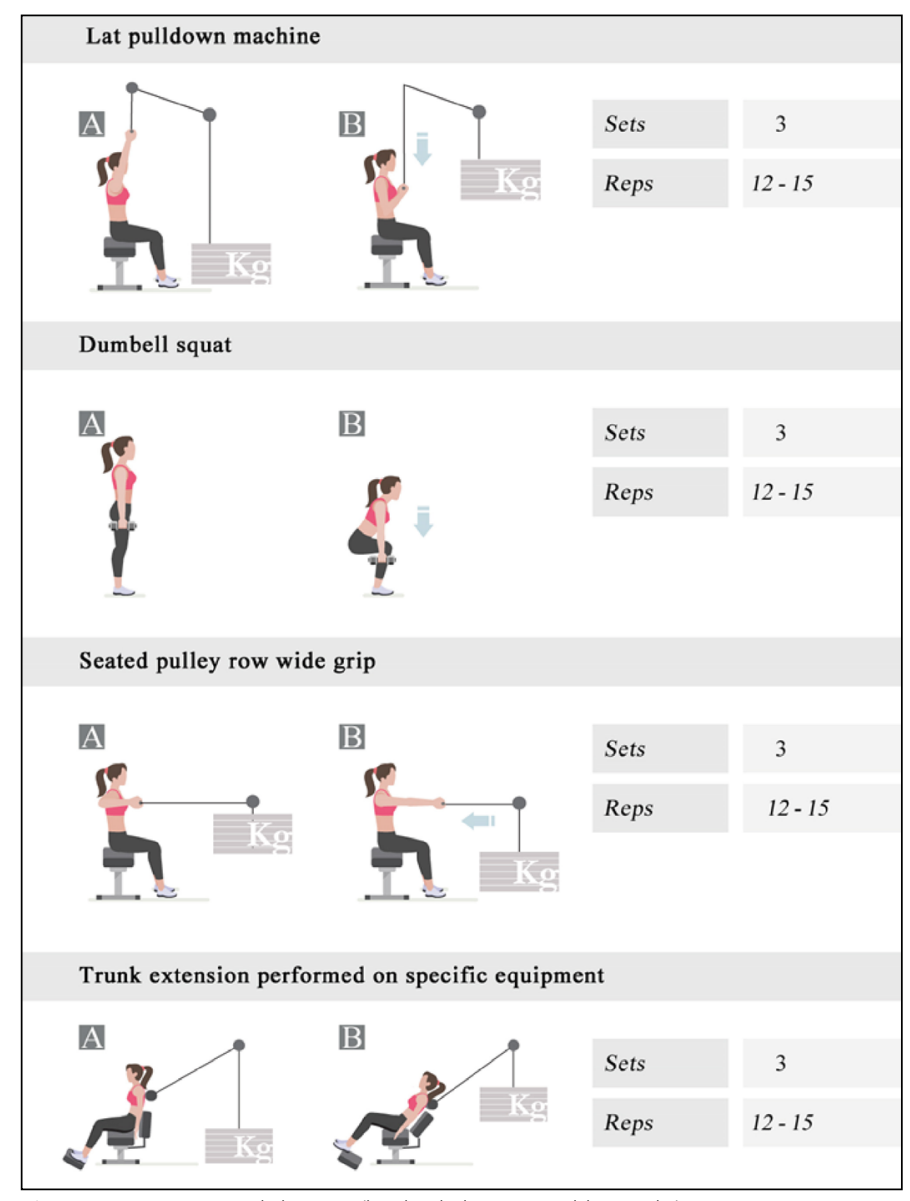

Figure 1. Training Worksheet A (back, abdomen and buttocks) - Resistance training group with weights.

Abdominal crunches performed on specific equipment
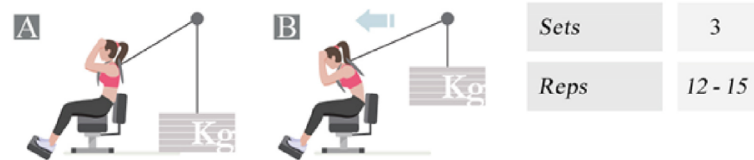

Abdutor machine

A

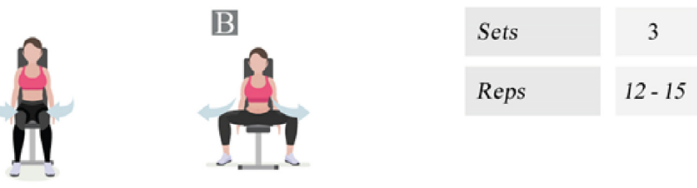

Abdominal crunches performed on high pulley

A

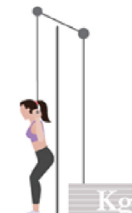

Lateral trunk flexion with dumbell

A

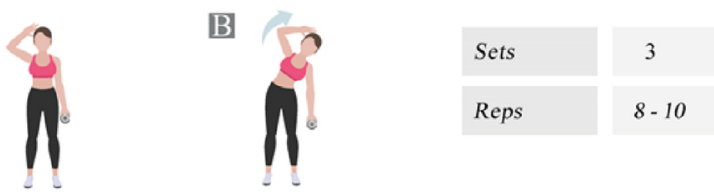

Figure 2. Training Worksheet A (back, abdomen and buttocks) - Resistance training group with weights.

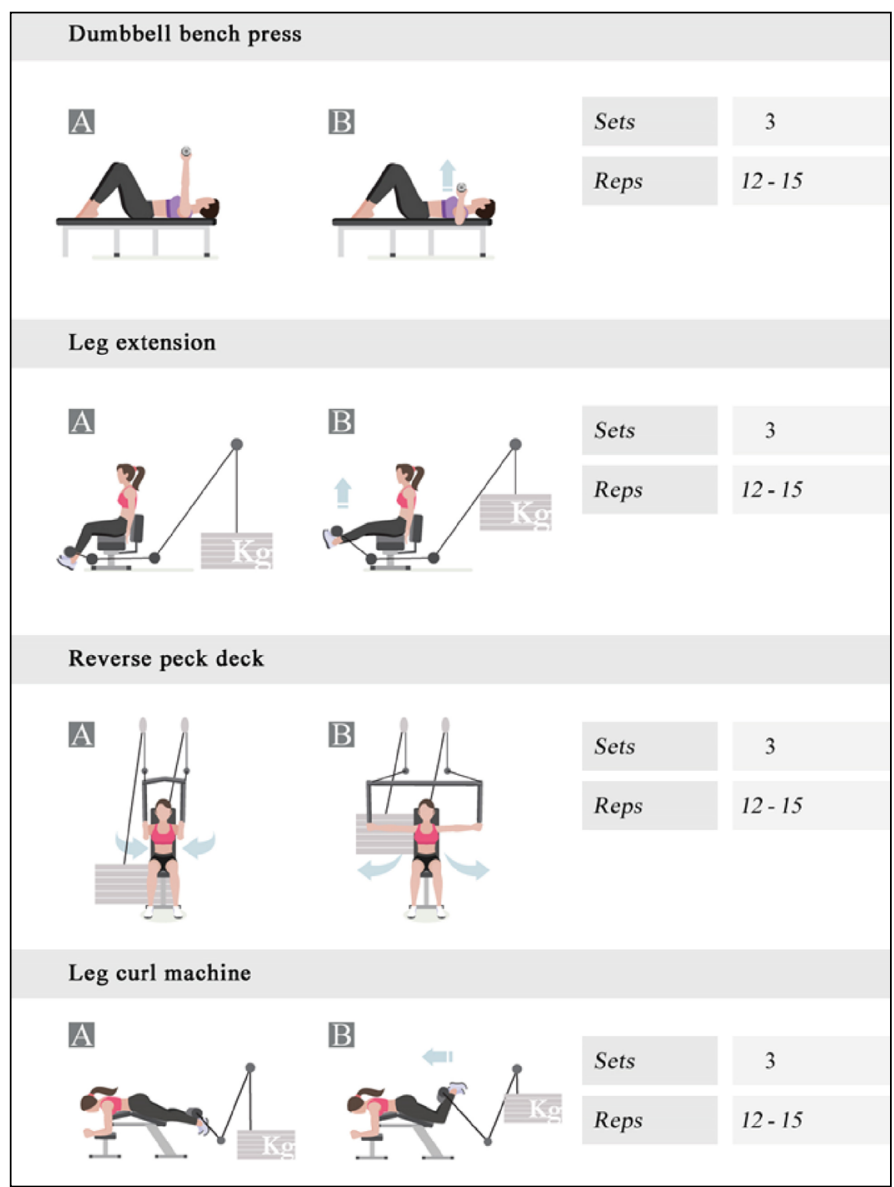

Figure 3. Training Worksheet B (chest, legs, shoulders, biceps and triceps) - Resistance training group with weights.

Alternating dumbbell curl (seated)

A

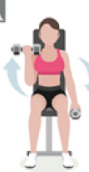

B

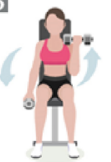

\begin{tabular}{l|c} 
Sets & 3 \\
Reps & $12-15$
\end{tabular}

Adductor machine

A

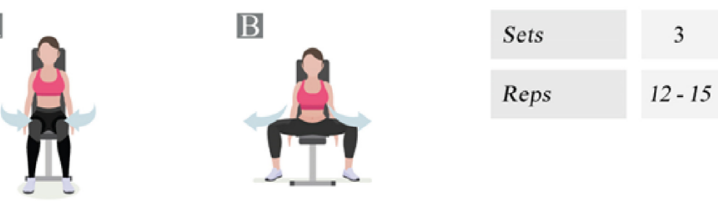

Tríceps on the high pulley, hands in pronation

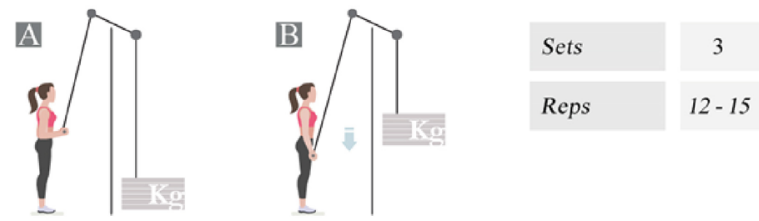

Rotary calf machine

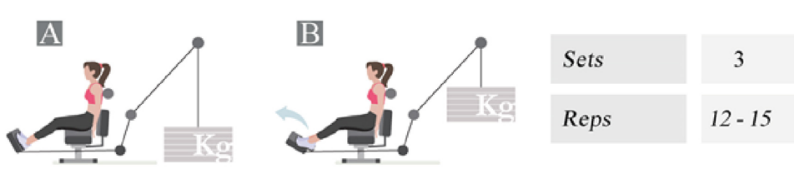

Figure 4. Training Worksheet B (chest, legs, shoulders, biceps and triceps) - Resistance training group with weights. 


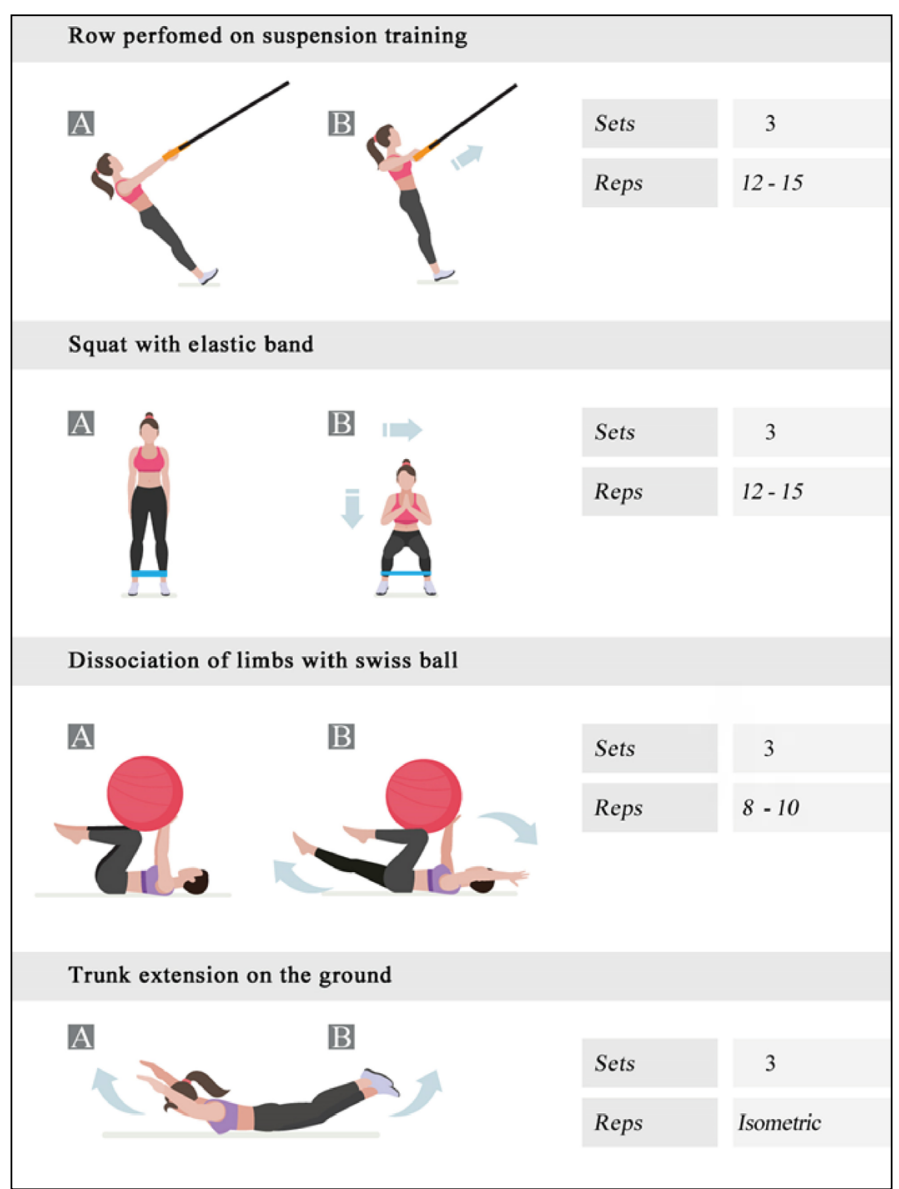

Figure 5. Training Worksheet A (back, abdomen and buttocks) - Resistance training group without weights.

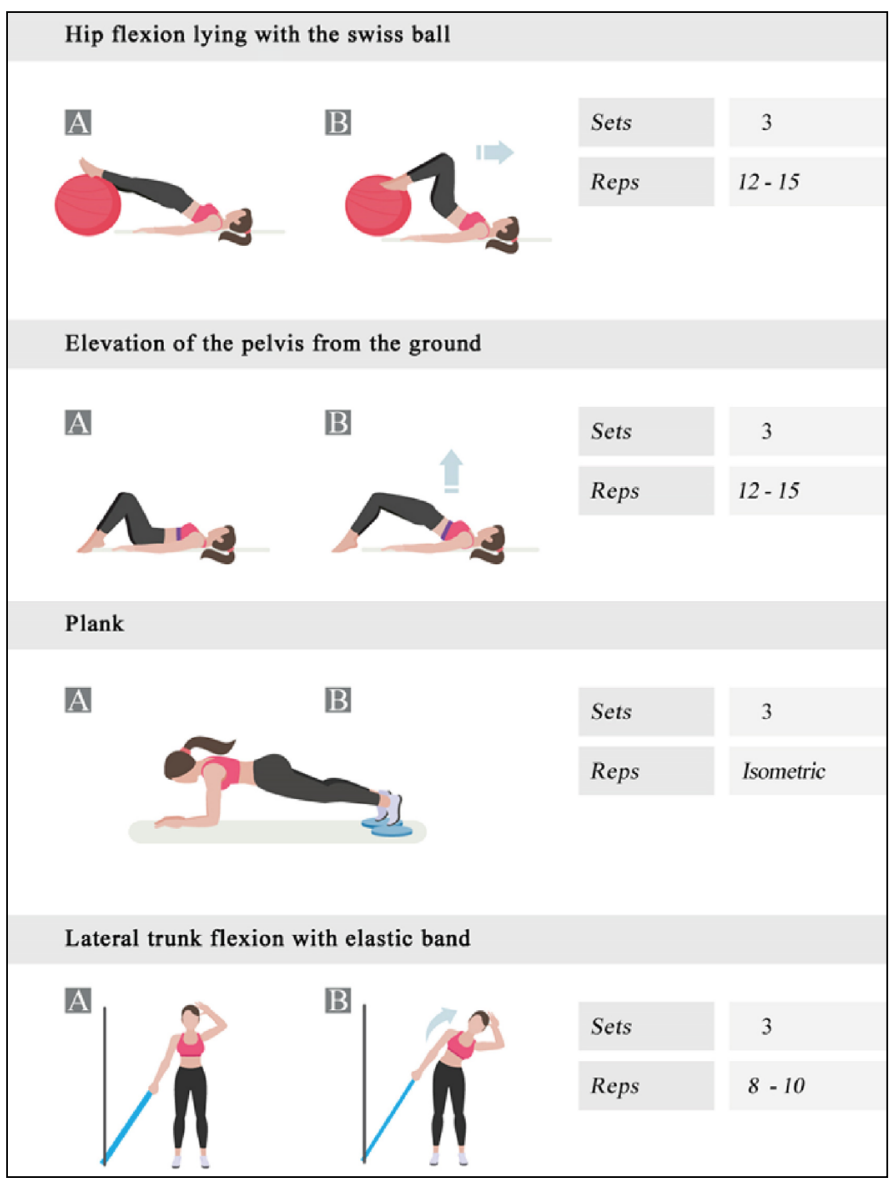

Figure 6. Training Worksheet A (back, abdômen and buutocks) - Resistance training group without weights.

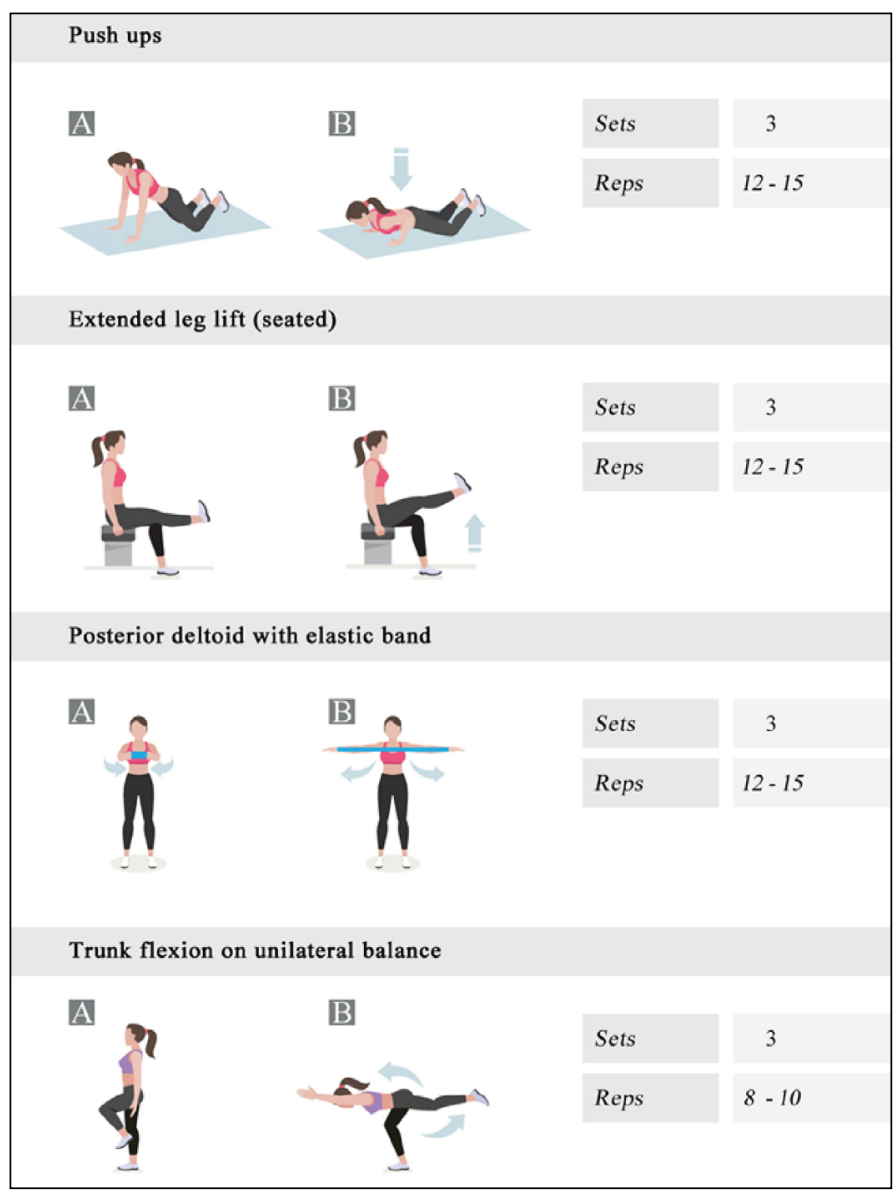

Figure 7. Training Worksheet B (chest, legs, shoulders, biceps and triceps) - Resistance training group without weights.

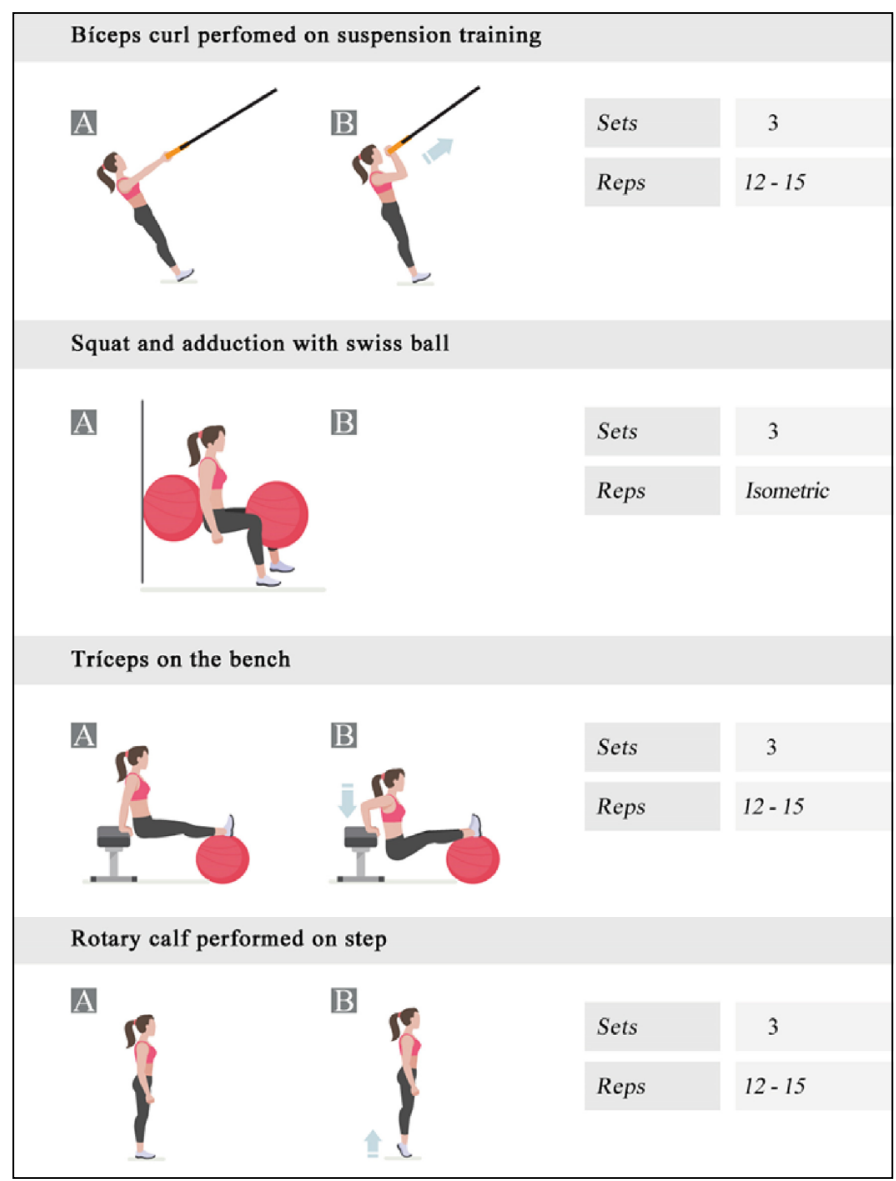

Figure 8. Training Worksheet B (chest, legs, shoulders, biceps and triceps) - Resistance training group without weights. 
did not perform physical exercises and the RTG1 and RTG2 groups had their adherence controlled by the responsible personal trainer.

The study was approved by the local ethics and research committee (CAAE: 51617215.4.000.5505) and included in the Brazilian Registry of Clinical Trials (UTN: U1111-1230-5315).

\section{Statistical methods}

To assess the difference of the intragroup variables of interest between the selected moments, we opted for the paired non-parametric Wilcoxon test, indicated in the situation where the assumptions made in the parametric tests are not verified. ${ }^{14}$ To compare the three study groups regarding the differences observed in the variables of interest, the Kruskal-Wallis non-parametric test was chosen. ${ }^{14}$ For all tests, the significance level was set at $5 \%$. All analyzes were performed with the aid of the statistical environment R (R Development Core Team), version 3.3.

\section{RESULTS}

The sample consisted of 30 volunteers, 10 in each group (RTG1, RTG2 and (G). The RTG1 group was composed of 70\% men and 30\% women; the RTG2 group for 30\% men and $70 \%$ women; and the CG for men and women, in the proportion of 50\%. Adherence among physically active groups was $96.25 \%$.

Analyzing the average values obtained for different evaluated parameters, comparing the initial moment and after eight weeks, it was observed that there was no significant difference for life quality in any of the groups: $\operatorname{RTG2}(p=0.0899), C G(p=0,3741)$ and RTG1 $(p=0.4237)$. On the other hand, in the function assessment (Oswestry Disability Index), it was found that all groups showed significant improvement in the following order: RTG2 ( $p=0.0177), \operatorname{RTG} 1(p=0.0239)$ and $C G(p=0,0410)$. Regarding flexibility and abdominal strength, only the physically active groups showed significant differences between baseline and 8 weeks. For flexibility, RTG1 ( $p=0.0245)$, TRSP $(p=0.0352)$ and CG $(p=0.1807)$. For abdominal strength, RTG1 $(p=0.243), \operatorname{RTG} 2(p=0.0090)$ and CG $(p=0.0797)$. Regarding the decrease in abdominal fat rate, only the RTG1 group showed results $(p=0.0281)$. (Figure 9$)$ (Table 1$)$.

It was not possible to detect a statistically significant difference between the groups for any of the evaluated outcomes (Table 2).

\section{DISCUSSION}

Exercise therapy provides benefits to patients with chronic low back pain through voluntary contraction of specific groups, movements of the whole body, activities that improve postural musculature, stabilization and neurological coordination, or combination. ${ }^{15}$

According to a study by Gatti et al. ${ }^{16}$, patients with chronic low back pain have an easier time performing core strengthening without

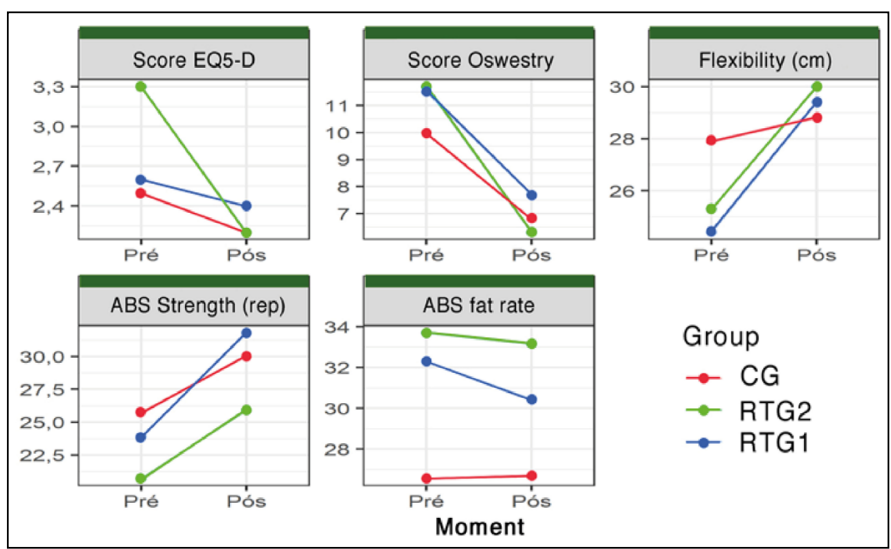

Figure 9. Graph of average measurement profiles of study participants before and after the intervention.
Table 1. Intragroup evaluation.

\begin{tabular}{|c|c|c|c|c|c|c|c|}
\hline Variables & Group & Moment & Average & DP & Median & IQR & P Value \\
\hline \multirow{6}{*}{ Score EQ5-D } & \multirow{2}{*}{$C G$} & Pre & 2,50 & 1,08 & 3,00 & 1,50 & \multirow{2}{*}{0,3741} \\
\hline & & Post & 2,20 & 1,32 & 2,00 & 1,75 & \\
\hline & \multirow{2}{*}{ RTG2 } & Pre & 3,30 & 1,89 & 3,50 & 2,50 & \multirow{2}{*}{0,0899} \\
\hline & & Post & 2,20 & 1,81 & 2,00 & 2,75 & \\
\hline & \multirow{2}{*}{ RTG1 } & Pre & 2,60 & 1,65 & 2,00 & 1,75 & \multirow{2}{*}{0,4237} \\
\hline & & Post & 2,40 & 1,35 & 2,00 & 1,75 & \\
\hline \multirow{6}{*}{$\begin{array}{c}\text { Oswestry } \\
\text { Score }\end{array}$} & \multirow{2}{*}{$C G$} & Pre & 10,00 & 4,64 & 10,00 & 8,25 & \multirow{2}{*}{$0,0410^{*}$} \\
\hline & & Post & 6,80 & 2,39 & 7,00 & 2,75 & \\
\hline & \multirow{2}{*}{ RTG2 } & Pre & 11,70 & 7,39 & 10,50 & 7,50 & \multirow{2}{*}{$0,0177^{*}$} \\
\hline & & Post & 6,30 & 6,00 & 5,00 & 9,25 & \\
\hline & \multirow{2}{*}{ RTG1 } & Pre & 11,50 & 8,22 & 8,50 & 11,25 & \multirow{2}{*}{$0,0239 *$} \\
\hline & & Post & 7,70 & 5,66 & 4,50 & 7,75 & \\
\hline \multirow{6}{*}{$\begin{array}{l}\text { Flexibility } \\
(\mathrm{cm})\end{array}$} & \multirow{2}{*}{$C G$} & Pre & 27,90 & 6,95 & 29,00 & 12,25 & \multirow{2}{*}{0,1807} \\
\hline & & Post & 28,80 & 7,50 & 30,50 & 12,00 & \\
\hline & \multirow{2}{*}{ RTG2 } & Pre & 25,30 & 11,69 & 26,00 & 9,00 & \multirow{2}{*}{$0,0352^{*}$} \\
\hline & & Post & 30,00 & 9,92 & 31,00 & 13,00 & \\
\hline & \multirow{2}{*}{ RTG1 } & Pre & 24,40 & 9,95 & 26,00 & 3,00 & \multirow{2}{*}{$0,0245^{*}$} \\
\hline & & Post & 29,40 & 6,43 & 30,50 & 3,75 & \\
\hline \multirow{6}{*}{$\begin{array}{c}\text { Abdom. } \\
\text { Strenght } \\
\text { (rep) }\end{array}$} & \multirow{2}{*}{$C G$} & Pre & 25,80 & 14,49 & 27,00 & 16,50 & \multirow{2}{*}{0,0797} \\
\hline & & Post & 30,00 & 14,09 & 30,00 & 17,00 & \\
\hline & \multirow{2}{*}{ RTG2 } & Pre & 20,70 & 6,77 & 20,50 & 5,00 & \multirow{2}{*}{$0,0090^{*}$} \\
\hline & & Post & 25,90 & 8,43 & 28,00 & 9,25 & \\
\hline & \multirow{2}{*}{ RTG1 } & Pre & 23,90 & 8,28 & 24,50 & 6,00 & \multirow{2}{*}{$0,0243^{*}$} \\
\hline & & Post & 31,80 & 8,89 & 34,50 & 14,50 & \\
\hline \multirow{6}{*}{$\begin{array}{l}\text { ABS fat } \\
\text { rate (\%) }\end{array}$} & \multirow{2}{*}{$C G$} & Pre & 26,55 & 9,95 & 27,50 & 10,25 & \\
\hline & & Post & 26,65 & 10,44 & 27,00 & 12,38 & \\
\hline & $R$ & Pre & 33,70 & 8,69 & 32,50 & 12,38 & \\
\hline & NIU⿺ & Post & 33,15 & 7,88 & 33,75 & 9,50 & 0,040 \\
\hline & & Pre & 32,30 & 8,53 & 33,50 & 13,00 & \\
\hline & nive & Post & 30,45 & 8,98 & 31,00 & 12,88 & \\
\hline
\end{tabular}

Note: ${ }^{*} \mathrm{p}$-value $<0.05 ; \mathrm{SD}=$ standard deviation; $\mathrm{IQR}=$ Interquartile range.

Table 2. Intergroups evaluation.

\begin{tabular}{|c|c|c|c|c|c|c|}
\hline Variables & Group & Average & DP & Median & IQR & P Value \\
\hline \multirow{3}{*}{ Score EQ5-D } & $C G$ & $-0,30$ & 0,95 & 0,00 & 1,00 & \multirow{3}{*}{0,4930} \\
\hline & RTG2 & $-1,10$ & 1,79 & $-0,50$ & 1,75 & \\
\hline & RTG1 & $-0,20$ & 0,63 & 0,00 & 0,75 & \\
\hline \multirow{3}{*}{ Oswestry Score } & CG & $-3,20$ & 3,99 & $-3,50$ & 3,50 & \multirow{3}{*}{0,4550} \\
\hline & RTG2 & $-5,40$ & 4,90 & $-6,00$ & 6,00 & \\
\hline & RTG1 & $-3,80$ & 3,77 & $-3,50$ & 3,50 & \\
\hline \multirow{3}{*}{ Flexibility (cm) } & $C G$ & 0,90 & 2,85 & 1,00 & 1,75 & \multirow{3}{*}{0,1539} \\
\hline & RTG2 & 4,70 & 5,66 & 3,50 & 6,75 & \\
\hline & RTG1 & 5,00 & 5,70 & 3,00 & 4,75 & \\
\hline \multirow{3}{*}{$\begin{array}{c}\text { Abdominal } \\
\text { strength. (rep) }\end{array}$} & $C G$ & 4,20 & 7,22 & 3,50 & 8,50 & \multirow{3}{*}{0,5833} \\
\hline & RTG2 & 5,20 & 3,43 & 5,50 & 4,75 & \\
\hline & RTG1 & 7,90 & 7,40 & 10,00 & 12,50 & \\
\hline \multirow{3}{*}{ ABS fat rate (\%) } & CG & 0,10 & 2,62 & $-0,25$ & 2,13 & \multirow{3}{*}{0,2192} \\
\hline & RTG2 & $-0,55$ & 3,71 & $-0,25$ & 5,88 & \\
\hline & RTG1 & $-1,85$ & 2,03 & $-2,50$ & 1,88 & \\
\hline
\end{tabular}

Note: $\mathrm{SD}=$ standard deviation; $\mathrm{IQR}=$ Interquartile range.

weights when compared to resistance training with weight training; confirming the trends found in this study, in which the perception of improved function was greater among the participants in the group that performed resistance training without weights.

Analyzing the function results, using the Oswetry Disability Index questionnaire, there was a significant difference between the evaluated moments for all groups. Even though the RTG1 achieved superior results in physical tests, this superiority did not correspond to the emotional, psychological and functional expectations of the study participants. In this 
instrument, the RTG2 indicated a tendency to be the most suitable for the treatment of chronic non-specific low back pain, a fact that may be related to the fear of a new pain crisis when exercising, especially with weights. ${ }^{17}$

The control group showing a significant improvement in function demonstrates the importance of the guidance and reception of patients with chronic non-specific low back pain in the specialized outpatient clinic and the positive effect of analgesic medication; however, the literature highlights the importance of physically active treatments.

For Keen et al. ${ }^{18}$, the development of educational programs for the prevention and treatment of low back pain through physical activity should be directed to promote knowledge, attitudes and behaviors compatible with a physically active social dynamic. As for the reduction in the disability rate, active rehabilitation showed better results when compared to rehabilitation without exercise, and this difference was even greater after one year. Other studies have also obtained good results for quality of life and function with a home program of functional exercises for the treatment of non-specific chronic low back pain. ${ }^{19}$

The measurement of flexibility was selected because there is several evidences, which link a lack of joint flexibility to a high risk of developing low back pain. ${ }^{20}$ Therefore, the inclusion of dynamic stretching exercises during the program periodization was essential. As, in general, this type of exercise is not performed on machines, this training step was performed together, without distinction of exercises between the RTG1 and RTG2 groups. For this outcome, the results were significant between the two active groups, in the intragroup assessment. Both had gains between the evaluated moments, which highlights the importance of maintaining / controlling good flexibility for the treatment of chronic nonspecific low back pain. Therefore, it cannot be said that weighted exercises decrease flexibility. ${ }^{21}$

Regarding abdominal strength, the association between weakness of the paravertebral muscles and, above all, abdominal muscles, and low back pain is emphasized. There is a consensus in the literature on the need to strengthen the deep trunk muscles in patients with chronic low back pain. ${ }^{22}$

The set of muscles responsible for maintaining trunk stability is called CORE. ${ }^{23}$ This group of muscles includes: abdominal muscles (transversus abdominis, internal and external obliques and rectus abdominis); lumbar muscles (lumbar multifidus, lumbar square and spine erector); diaphragm; pelvic floor and buttock muscles (especially the middle glutes). ${ }^{24}$

Abdominal contraction provides segmental stability of the spine and keeps it within a neutral zone. ${ }^{25}$ Due to such evidence, one of the weekly training sessions was aimed only at strengthening this region, and the abdominal strength test was included to verify which of the tested modalities would be more effective for this outcome. The results showed that both approaches were effective, with resistance training with weights standing out in the intragroup assessment.

The measurement of the abdominal skinfold was performed to analyze the hypothesis that the biomechanical imbalance caused, sometimes, by the increase of fat in this region could cause a greater demand of the lumbar musculature, promoting pain.17 In this way, the decrease of the abdominal fat rate was also an outcome evaluated in the proposed training. The results found were significant only for RTG1 patients, in the intra-group evaluation, highlighting the effectiveness of bodybuilding as a potent stimulus for reducing body fat rate. ${ }^{26}$

No significant differences were found in this study when comparing the three groups, probably due to the limited number of participants. In a 24-month follow-up study, Michaelson et al. obtained similar results when comparing high-load lifting exercises and low-load motor control exercises, after performing an eight-week program. The results found also showed no statistically significant differences between the interventions, both of which showed positive results for improving function in the treatment of non-specific chronic low back pain. ${ }^{27}$

In the study, it was possible to blind the evaluator and randomize the three groups, since some participants were not available to attend the rehabilitation center during training days and times as previously scheduled.

The small number of participants was an important limitation of the study, and it was not possible to find significant differences in the intergroup comparison. Thus, we sought to value the improvement obtained for most outcomes in the intra-group assessments, and especially the experience of living with the participants during the 8 weeks of training, when, even subjectively, satisfaction and evolution were clear.

\section{CONCLUSION}

The exercise program, carried out over an eight-week period, both with resistance training with weights, and with resistance training without weights, was effective in improving abdominal function, flexibility and strength in patients with non-specific chronic low back pain. There was no statistically significant improvement in life quality in any of the groups evaluated. Only the group that performed resistance training with weights showed a significant decrease in abdominal fat rate.

When comparing the groups: there was no significant difference for any of the evaluated outcomes.

All authors declare no potential conflict of interest related to this article

AUTHORS' CONTRIBUTIONS: Each author made significant individual contributions to this manuscript. Oliveira CT: main contribution to the conception and design of the study, trainer responsible for the exercise sessions applied in the treatment, acquisition and interpretation of the data and writing the text. Kanas M: substantial contribution to the study design, medical care of the participants of the sample, as well as critical review of the intellectual content of the work. Wachenberg M: substantial contribution to the study design, critical review of the intellectual content and final approval of the version of the manuscript to be published.

\section{REFERENCES}

1. Middelkoop MV, Rubinstein SM, Verhagen AP, Ostelo RW, Koes BW, van Tulder MW. Exercise therapy for chronic nonspecific low-back pain. Best Pratice \& Research Clinical Rheumatology. 2010.24(2):193-204.

2. Rached RD, Rosa CD, Alfieri MF, Amaro SM et al. Lombalgia inespecífica crônica: reabilitação. Associação Brasileira de Medicina Física e Reabilitação. 2011.59(6):99-13.

3. Van Tulder M, Becker A, Bekkering, Breen A, Del Real M, Hutchinson A et al. European guidelines for the management of acute nonspecific low back pain in primary care. Eur Spine J. 2006. 3(2)169-91.

4. Andrade SC, Araújo AG, Vilar MJ. Escola de coluna: revisão histórica e sua aplicação na lombalgia crônica. Rev Bras Reumatol. 2005. 45(4):224-28.

5. Hayden JA, Cartwright JL, Riley RD, Vantulder MW, Chronic Low Back Pain IPDMAG. 2012. Exercise therapy for chronic low back pain: protocol for an individual participant data meta-analysis. Syst Rev. 2012. 1(64):64.

6. Krismer M, Van Tulder M, Strategies for prevention and management of musculoskeletal conditions. Low back pain (non-specific). Best Pract Res Clin Res Clin Rheumatol. 2007. 21(1)77-91.

7. Van Tulder M, Malmivaara A, Esmail R, Koes BW. Exercise therapy for low back pain: a sistematic review. Cochrane Database Syst Rev. 2000. 25(21):2784-96

8. Wells KF, Dillon EK. The sit and reach - a test of back and leg flexibility. Res Quart. 1952; 23:115-8.
9. Matsudo VKR. Testes em ciência do esporte. 4.ed. São Caetano do Sul: Gráficos Burti Ltda; 1987. $152 p$.

10. Pollock ML, Wilmore JH. Exercícios na saúde e na doença: avaliação e prescrição para prevenção e reabilitação. 2.ed. Rio de Janeiro: Medsi; 1993.

11. EuroQol Group. EuroQol - A new facility for the measurement of health-related quality of live. Health Policy. 1990.16(3):199-208.

12. Vigatto R, Alexandre NMC, Correa Filho HR. Development of Brazilian Portuguese version of the Oswestry Disability Index: cross-cultural adaptation, reliability, and valitidy. Spine (Phi Pa 1976). 2007; 32(4):481-6.

13. Chang WD, Lin HY, Lai PT. Core strength training for patients with chronic low back pain. J Phys Ther Sci. 2015 Mar; 27(3):619-22.

14. Sheskin D. Handbook of parametric and nonparametric statistical procedures. 3.ed. London: Chapman \& Hall/CRC; 2003

15. Powell KE, Paluch AE, Blair SN. Physical activity for health: what kind? How much? How intense? On top of what? Annual Review of Public Health. 2011. 32(1):349-65

16. Gatti R, Faccendini S, Tettamanti A, Barbeiro M, Balestri A, Calori G. Efficacy of trunk balance exercises 
for individuals with chronic low back pain: a randomized clinical trial. J Ortho Sports Phys Ther. 2011. 41(8):542-52

17. Toscano JJO, Egypto EP. A influência do sedentarismo na prevalência de lombalgia. Rev Bras Med Esporte. 2001.7(4):132-137.

18. Lizier DT, Perez MV, Sakata RK. Exercícios para tratamento de lombalgia inespecífica. Revista Brasileira de Anestesiologia. 2012.62(6):842-46.

19. Kanas M. Eficácia de um programa domiciliar de exercícios no tratamento da dor lombar crônica inespecífica. [Mestrado profissional em Ciências da Saúde Aplicada ao Esporte e à Atividade Física]. São Paulo: Escola Paulista de Medicina, Universidade Federal de São Paulo; 2017. 86p.

20. Ouro GC, Araújo PC, Limana MD, Garcez VF. Análise da flexibilidade em indivíduos com lombalgia. In: VII Mostra Interna de Trabalhos de Iniciação Científica. UNICESUMAR - Centro Universitário de Maringá. 2014. 21-24.

21. Fleck SJ, Kraemer WJ. Fundamentos do treinamento de força muscular. 2.ed. Porto Alegre: Artmed: 1999.247p.

22. Schilling JF, Murphy JC, Bonney JR, Thich JL. Effect of core strength and endurance training on performance in college students: randomized pilot study. J Bodyw Mov Ther. 2013. 17(3):278-90.

23. Aluko A, DeSouza L, Peacock J. The effect of core stability exercises on variations in acceleration of trunk movement, pain end disability during an episode of acute nonspecific low back pain: a pilot clinical trial. J Manipulative Physiol Ther. 2013. 36(8):497-04.

24. Huang JT, Chen HY, Hong CZ, Ming-Ta Lin, Li-Wei Chou, Hsin-Shui Chen, ChienTsung Tsai, Wen-Dien Chang. Lumbar facet injection for the treatment of chronic piriformis myofascial pain syndrome: 52 case studies. Patient Prefer Adherence. 2014. 8(7):1105-11.

25. Wong AY, Parent EC, Funabashi M, Stanton TR, Kawchuck GN. Do various baseline characteristics of transversus abdominis and lumbar multifidus predict clinical outcomes in nonspecific low back pain? A systematic review. Pain. 2013. 154(12):2589-602.

26. Scussolin T, Navarro A. Musculação, uma alternativa válida para o tratamento da obesidade. Revista brasileira de obesidade, nutrição e emagrecimento. 2007. 1(6):74-83.

27. Michaelson P, Holmberg D, Aasa B, Aasa U. High load lifting exercise and low load motor control exercises as interventions for patients with mechanical low back pain: A randomised controlled trial with 24 month follow-up. J Rehabil Med. 2016. 48(5):456-63. 